\title{
10 CFR 830 Major Modification Determination for Emergency Firewater Injection System Replacement
}

May 2011

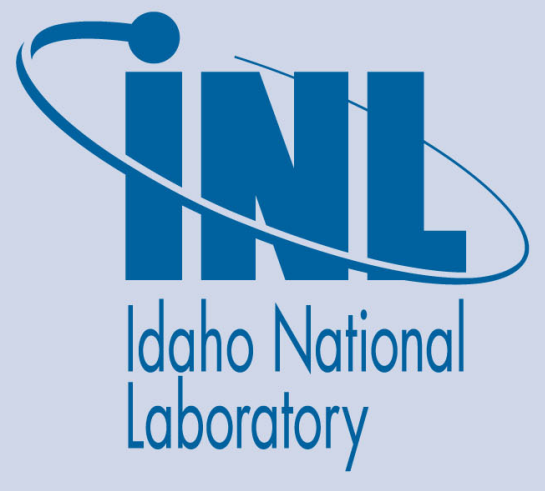

The INL is a U.S. Department of Energy National Laboratory operated by Battelle Energy Alliance 
INL/EXT-11-22066

\title{
10 CFR 830 Major Modification Determination for Emergency Firewater Injection System Replacement
}

May 2011

\author{
Idaho National Laboratory \\ Idaho Falls, Idaho 83415
}

http://www.inl.gov

Prepared for the

U.S. Department of Energy

Office of Nuclear Energy

Under DOE Idaho Operations Office

Contract DE-AC07-05ID14517 
INL/EXT-11-22066

Revision 0

\section{DISCLAIMER}

This information was prepared as an account of work sponsored by an agency of the U.S. Government. Neither the U.S. Government nor any agency thereof, nor any of their employees, makes any warranty, expressed or implied, or assumes any legal liability or responsibility for the accuracy, completeness, or usefulness, of any information, apparatus, product, or process disclosed, or represents that its use would not infringe privately owned rights. References herein to any specific commercial product, process, or service by trade name, trade mark, manufacturer, or otherwise, does not necessarily constitute or imply its endorsement, recommendation, or favoring by the U.S. Government or any agency thereof. The views and opinions of authors expressed herein do not necessarily state or reflect those of the U.S. Government or any agency thereof. 
INL/EXT-11-22066

Revision 0

\author{
Advanced Test Reactor
}

\title{
10 CFR 830 Major Modification Determination \\ for
}

\section{Emergency Firewater Injection System Replacement}

\author{
INL/EXT-11-22066 \\ Revision 0
}

May 2011

Developed by:
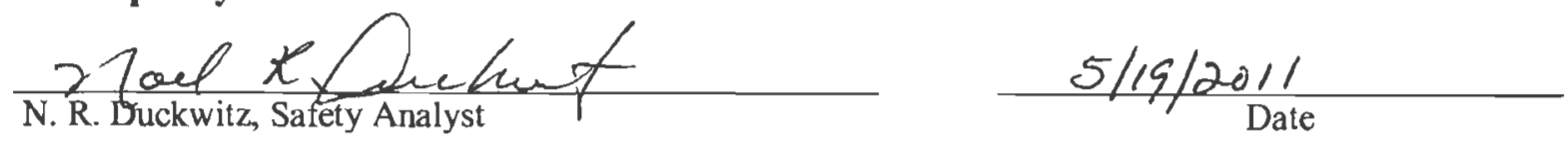

Approved by:

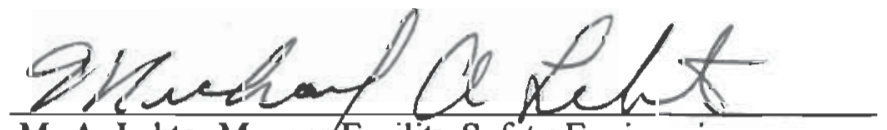

M. A. Lehto, Manger/Facility Safety Engineering

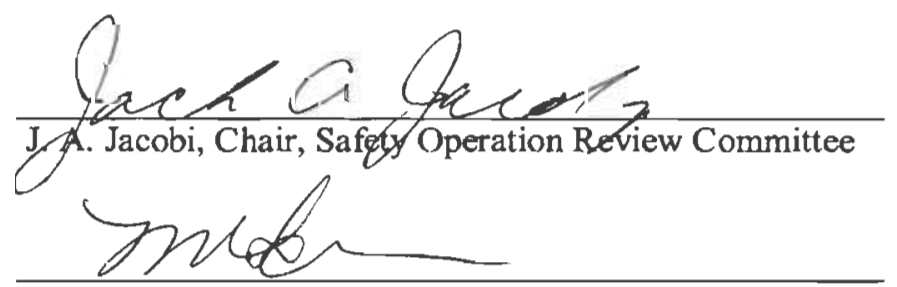

M. DLLove, Director ATR Complex operA trons

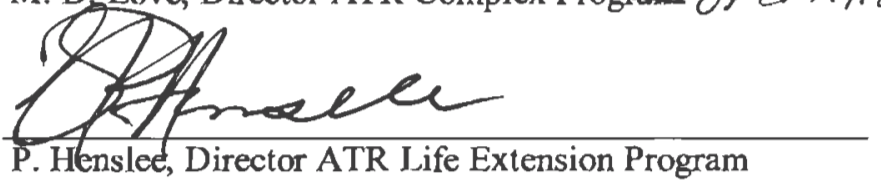

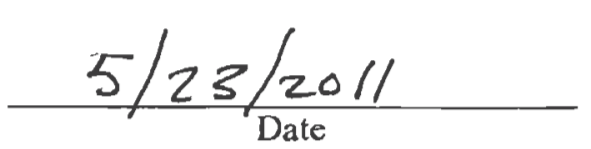

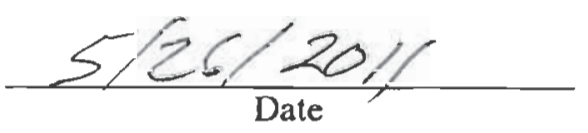

$6 / 2 / 2011$

$$
\text { Date }
$$

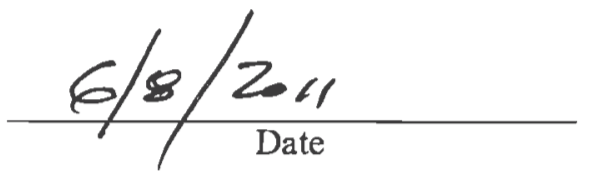


INL/EXT-11-22066

Revision 0

\section{CONTENTS}

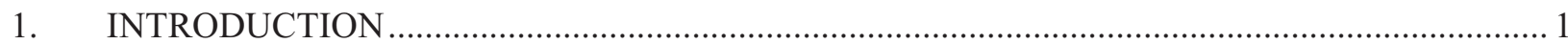

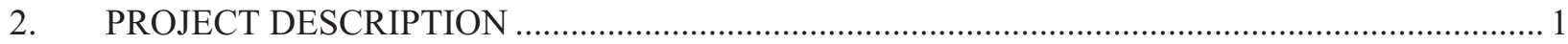

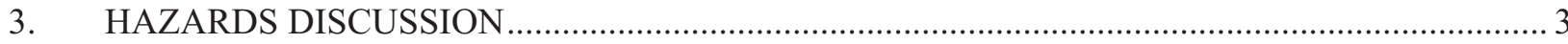

4. MAJOR MODIFICATION EVALUATION CRITERIA …....................................................

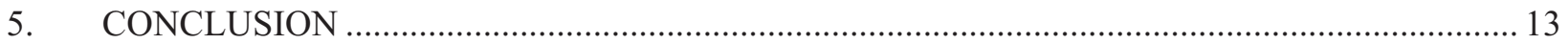

TABLES

Table 1. Major Modification Evaluation Criteria ............................................................................... 6

FIGURES

Figure 1 Replacement Emergency Firewater Injection System Concept (New Equipment in Red) ........... 4

Figure 2 - Facility Modification Process (taken from DOE-STD-1189, Fig 8-1)................................... 12 


\section{DEFINITIONS}

Major modification - A modification to a DOE nuclear facility that is completed on or after May 9, 2001 that substantially changes the existing safety basis for the facility. (10 CFR 830)

Nuclear facility - A reactor or a nonreactor nuclear facility where an activity is conducted for or on behalf of DOE and includes any related area, structure, facility, or activity to the extent necessary to ensure proper implementation of the requirements established by 10 CFR 830. (10 CFR 830)

Safety basis - The documented safety analysis and hazard controls that provide reasonable assurance that a DOE nuclear facility can be operated safely in a manner that adequately protects workers, the public, and the environment. (10 CFR 830)

Simple modification - A modification to a DOE nuclear facility not requiring a new or revised hazard analysis and accident analysis and new safety controls. (DOE-STD-1189)

Substantial change to the existing safety basis - Required by facility modification that is considered a major modification. (DOE-STD-1189) 


\section{ACRONYMS and ABBREVIATIONS}

\begin{tabular}{|c|c|}
\hline ATR & Advanced Test Reactor \\
\hline CFR & Code of Federal Regulation \\
\hline CLOHS & complete loss of heat sink \\
\hline CSDR & conceptual safety design report \\
\hline DOE & U.S. Department of Energy \\
\hline EDG & emergency diesel generator \\
\hline EFIS & emergency firewater injection system \\
\hline GFE & government furnished equipment \\
\hline $\mathrm{HC}$ & hazard category \\
\hline INL & Idaho National Laboratory \\
\hline LDW & low pressure demineralized water \\
\hline LOCA & loss-of-coolant-accident \\
\hline MAR & material-at-risk \\
\hline NPH & natural phenomena hazards \\
\hline $\mathrm{PC}$ & performance category \\
\hline PCS & primary coolant system \\
\hline PDSA & preliminary documented safety analysis \\
\hline PSDR & preliminary safety design report \\
\hline SAR & safety analysis report \\
\hline $\mathrm{SC}$ & safety class \\
\hline SDS & safety design strategy \\
\hline SS & safety significant \\
\hline $\mathrm{SSC}$ & structure, system or component \\
\hline STD & standard \\
\hline UFSAR & updated final safety analysis report \\
\hline
\end{tabular}


INL/EXT-11-22066

Revision 0

\title{
10 CFR 830 Major Modification Determination
}

\author{
for \\ Emergency Firewater Injection System Replacement
}

\section{INTRODUCTION}

The Advanced Test Reactor (ATR), located in the Advanced Test Reactor Complex of the Idaho National Laboratory (INL), was constructed in the 1960s for the purpose of irradiating reactor fuels and materials. Other irradiation services, such as radioisotope production, are also performed at ATR.

The continued safe and reliable operation of the ATR is critical to the Department of Energy (DOE) Office of Nuclear Energy (NE) mission. While ATR is safely fulfilling current mission requirements, a variety of aging and obsolescence issues challenge ATR engineering and maintenance personnel's capability to sustain ATR over the long term. First documented in a series of independent assessments, beginning with an OA Environmental Safety and Health Assessment conducted in 2003, the issues were validated in a detailed Material Condition Assessment (MCA) conducted as a part of the ATR Life Extension Program in 2007.Accordingly, near term replacement of aging and obsolescent original ATR equipment has become important to ensure ATR capability in support of NE's long term national missions. To that end, a mission needs statement has been prepared for a non-major system acquisition which is comprised of three interdependent sub-projects. The first project will replace the existent dieselelectrical bus (E-3), switchgear, and the 50-year-old obsolescent marine diesels with commercial power that is backed with safety-related emergency diesel generators (EDGs), switchgear, and uninterruptible power supply. The second project will replace the four, obsolete, original primary coolant pumps and motors. The third project, the subject of this major modification determination, will replace the current emergency firewater injection system (EFIS). The replacement water injection system will function as the primary emergency water injection system with the EFIS being retained as a defense-in-depth backup.

Completion of this and the two other age-related projects (replacement of the ATR diesel bus (E-3) and switchgear and replacement of the existent aged primary coolant pumps and motors) will resolve major age-related operational issues plus make a significant contribution in sustaining the ATR safety and reliability profile.

\section{PROJECT DESCRIPTION}

This project description is based on the drafted Mission Need Statement for Advanced Test Reactor Reliability Sustainment Project ${ }^{1}$ and scoping estimate supporting information for the ATR EFIS replacement system. ${ }^{2}$

The current emergency core cooling capability is comprised of equipment (pumps, valves, piping and tanks) with two redundant piping loops supplying water for core cooling from the plant's fire main system. The system is designed to mitigate severe upset scenarios during which the primary coolant flow through the reactor is critically disrupted. The current emergency response system, identified as the EFIS, if activated, either automatically or manually, supplies untreated well water under pressure for post-upset decay heat removal. Actuation of the system is anticipated to eventually result in flooding ATR to ground level. While it is technically feasible to restore ATR once the causative upset(s) is/are stabilized, restoration to permit restart would be challenging due to the extent of peripheral damage that will result from flooding large areas of the ATR building. 
Given the age of the current system and the need to replace a number of its components to overcome various obsolescence issues, it is appropriate that available technology and commercial experience, as applicable, be incorporated in the design of the replacement system. To that end, a system that incorporates a recirculation capability, utilizing reactor grade water, is recommended [low pressure demineralized water (LDW) is available and suitable for this purpose]. Such a system, unlike the existing system, will, by design, have the advantage that it can be tested periodically to prove its readiness. Lastly, with the addition of a limited scope remote water level and plant pressure management capability, should the existent control room require evacuation as currently required under select upset scenarios, the proposed system's functionality will be able to be controlled locally or remotely. This capability will aid in minimizing ancillary damage and, thereby, speed plant recovery.

As proposed, the replacement system with appropriate instrumentation (water level and temperature) will be designed to prevent unlimited facility flooding (the current outcome should the existent system be activated). Selected basement areas can serve as system sumps (high and low) which, served by appropriate replacement pumps and demineralized water augmentation, will, by design, avoid unlimited facility flooding. Replacing the existing untreated water injection system as proposed provides the necessary capability for facility restart on upset stabilization, accident remediation, and readily accomplished dewatering of the selected "sump" areas. The redesigned system sustains ATR capability for the long term in full support of projected mission requirements.

Preliminary functional and operational requirements and criteria for the EFIS replacement include the following:

- Provide controlled injection of cooling water and transition to long-term cooling even as retention of EFIS, in a non-safety configuration, will enhance defense-in-depth via continued access to the aquifer.

- Inject reactor grade water into the primary coolant system.

- Provide capability for system control from the ATR control room and/or from an alternative location.

Based on pre-conceptual studies to date, the following potential major system configuration attributes have been identified: (Note that further system studies may identify the need for changes.) (A notional system P\&ID is depicted below in Figure 1.)

- A safety-related cooling water injection system to provide injection into the PCS to mitigate a design basis loss-of-coolant-accident (LOCA). The EFIS replacement is comprised of two independent safety-related pumped injection trains to inject demineralized water into the plant to mitigate a LOCA. One train injects into bottom head EFIS to keep the core covered during a very large break LOCA. The other train injects into the PCS at a location equivalent to the LDW flush valve, for diversity and to maximize injection flow. Based on pre-conceptual studies, it is assumed for purposes of this major modification determination that the replacement EFIS injection pumps and associated valves will be housed in a new PC-4 structure.

- A recirculation system with vertical turbine pumps taking suction from the subbasement and injecting into the PCS, to maintain PCS inventory and permit managing the accident long-term until establishment of a terminal plant state without uncontrolled flooding of the reactor building. One recirculation train injects into the bottom head EFIS penetrations to maintain the core covered long term during a very large break LOCA. The second recirculation train injects into the PCS at the equivalent of the LDW flush valve location for diversity and to maximize flow.

- A replacement safety-related demineralized water tank with a usable water volume of 750,000 gallons. 
- A let-down system downstream of the existing vessel vent valves to control plant pressure in a range that permits the injection system to provide cooling water during a complete loss of heat sink (CLOHS) accident.

- The replacement EFIS injection and recirculation pumps will be powered from the replacement safety-related E-3 bus that is backed up with safety-related quick start emergency diesel generators. The replacement E-3 bus and EDGs are proposed and discussed under a separate but interrelated project that will be completed prior to this project.

- Upgrading the existing plant pressurizing pumps and associated systems to safety-related to provide cooling water for a CLOHS accident.

- The EFIS replacement will function as the primary safety-related emergency injection system for response to LOCA events. The current EFIS will be retained as a defense-in-depth system.

\section{HAZARDS DISCUSSION}

\section{Material at Risk}

The ATR material at risk (MAR) consists of the reactor core, radioactive material (irradiated fuel elements and other hardware) stored in the canal, isotope production targets, experiments containing fuel and non-fueled components. The ATR is a Category A reactor with an operating power level up to $250 \mathrm{MW}_{\mathrm{t}}$ and, as such, has a radioactive material inventory with the potential for significant off-site consequences. The proposed project has no effect on the quantity of MAR.

\section{Fires and/or Explosions}

The replacement system, as envisioned in the scoping studies, does not introduce any new fire/explosion hazards.

\section{Natural Phenomena Hazards}

Natural phenomena hazards (NPHs), including earthquakes (seismic events), extreme wind, tornado, flood, volcanic, and lightning, are potential hazards to the facility for causing building damage and/or failure of safety-related operational equipment. These NPH hazards were evaluated in the ATR Upgraded Final Safety Analysis (UFSAR) ${ }^{3}$ for existing facilities in support of current operations. As documented in the UFSAR, the current EFIS is comprised of the upper vessel subsystem, the bottom head subsystem, and the EFIS actuation system. The EFIS is classified as a safety-related engineered safety feature (Category - Plant Protection System). The EFIS is qualified as an active Seismic Category I component (i.e., active components functions are required to function in an accident/NPH environment). Water for the EFIS is supplied from the firewater supply system by two safety-related, diesel-operated firewater pumps (668-M-1 and 688-M-2). The pumps and their associated active support components are categorized as non-plant protective system, active Seismic Category I components (i.e. the pumps/engines are required to function in an accident/NPH environment). 


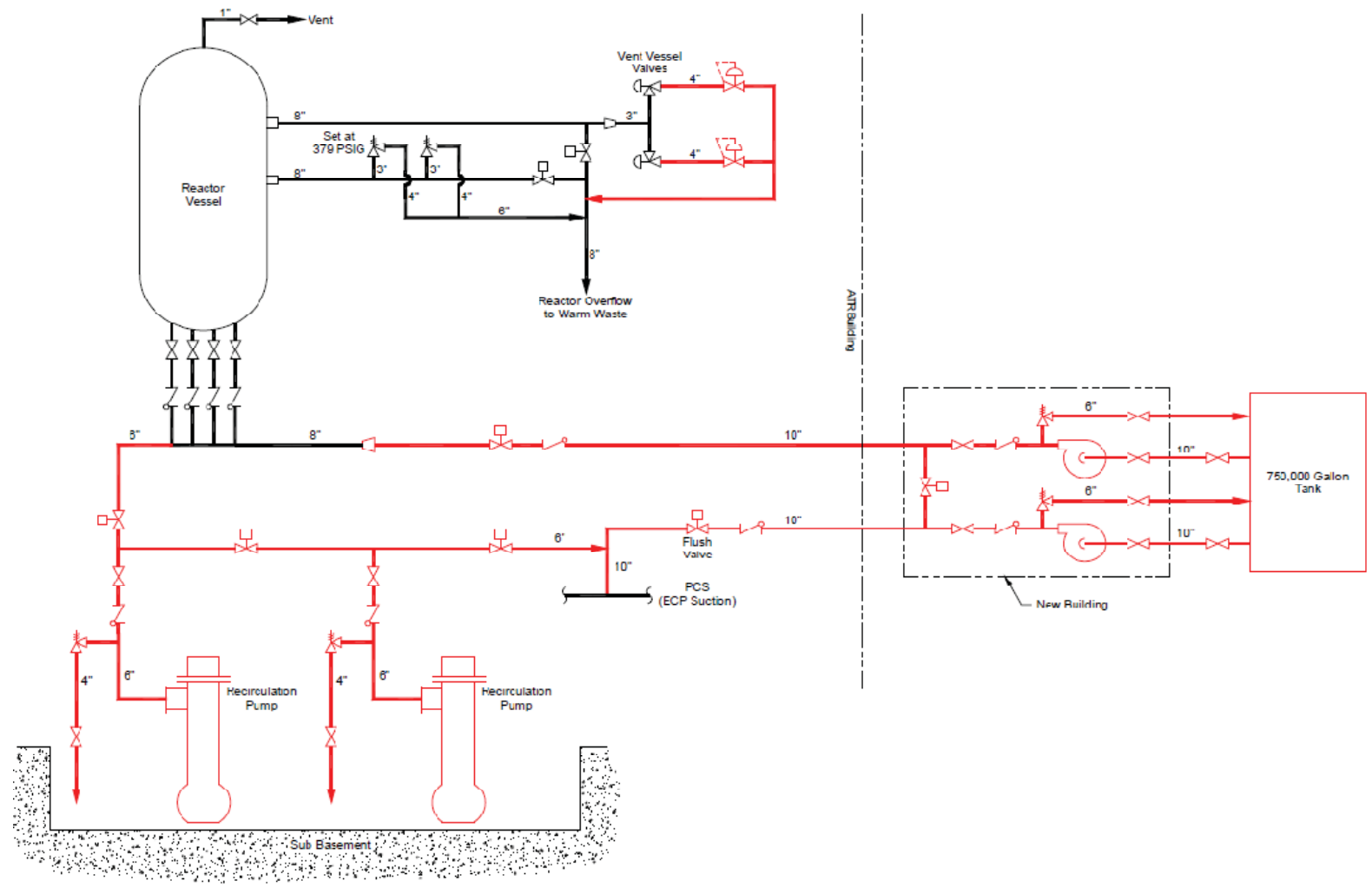

Figure 1. Replacement emergency firewater injection system concept (new equipment in red). 


\section{MAJOR MODIFICATION EVALUATION CRITERIA}

DOE-STD-1189-2008, "Integration of Safety into the Design Process," "was developed to provide consistent DOE complex-wide criteria to be used in determining if a change constitutes a major modification. The standard includes Table 8-1, "Major Modification Evaluation Criteria." The table provides a methodology for evaluating a project against the 10 CFR 830, "Nuclear Safety Management,", major modification evaluation criteria and was used as a basis for this major modification determination. The table is reproduced herein as Table 1, "Major Modification Evaluation Criteria." The purpose of Table 1 is to focus on the nature of the modification and the associated impact on the existing facility safety basis for the ATR facility.

Major modifications are defined as those changes that "substantially change the existing safety basis for the facility." The guidance for applying the table states that in applying the criteria, the intent is not to automatically trigger the need for a preliminary documented safety analysis (PDSA) if one or more of the criteria are met. Rather, it is intended that each criterion be assessed individually and then an integrated evaluation be performed based on the collective set of individual results. In performing this evaluation, the focus should be on the nature of the modification and its associated impact on the existing facility safety basis. Even a project that results in changes that ripple through the safety basis documents does not "substantially change the existing safety basis for the facility" solely because many parts or pages of the safety basis documentation need to be revised.

A major modification requires the development of a PDSA per 10 CFR 830.206, following the facility modification process as depicted in Figure 2. Since DOE-STD-3009, "Preparation Guide for U. S. Department of Energy Nonreactor Nuclear Facility Documented Safety Analyses," ${ }^{6}$ is not the safe harbor format for the ATR UFSAR, the safety design strategy (SDS) must establish the expectations and the format for integrating the subject major modifications to the update of the UFSAR. 
Table 1. Major modification evaluation criteria.

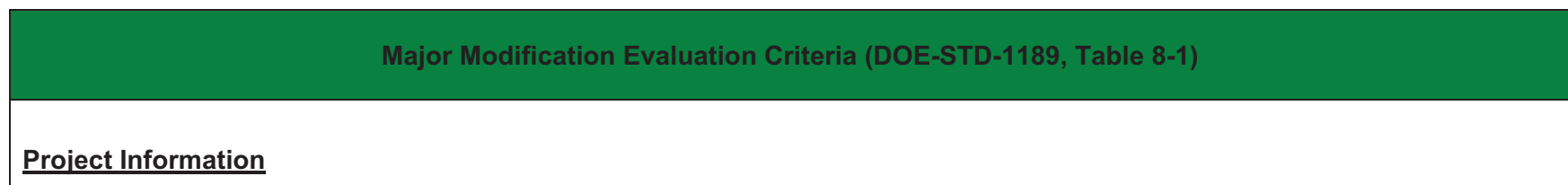

As envisioned in scoping documents, the proposed project will install a replacement for ATR's EFIS to provide water injection into the PCS to mitigate a LOCA. The EFIS replacement is comprised of two independent safety-related pumped injection trains to inject demineralized water into the plant to mitigate a LOCA. One train injects into present bottom head EFIS injection points to keep the core covered during a very large break LOCA. The other train injects into the PCS at a location equivalent to the LDW flush valve, for diversity and to improve thermal margins during design basis LOCAs. Based on pre-conceptual studies, it is assumed that the replacement EFIS injection pumps and associated valves will be housed in a new PC-4 structure. The replacement EFIS will function as the primary safety-related emergency injection system for response to LOCA events. The current EFIS will be retained as a defense-in-depth system.

The replacement EFIS will include a recirculation system with vertical turbine pumps taking suction from the reactor building subbasement and injecting into the PCS to maintain PCS inventory and permit managing the accident long-term until establishment of a terminal plant state without uncontrolled flooding of the reactor building. One recirculation train injects into the bottom head EFIS penetrations to maintain the core covered long term during a very large break LOCA. The second recirculation train injects into the PCS at the equivalent of the LDW flush valve location for diversity and to maximize flow. For purposes of this major modification determination, it is assumed that the replacement EFIS injection and recirculation pumps will be powered from the new safety-related E-3 bus that is backed up with safety-related quick start emergency diesel generators. The new E-3 bus and EDGs are proposed and discussed under a separate but interrelated project that will be completed prior to this project.

As envisioned, the replacement EFIS includes a replacement safety-related demineralized water tank with a usable water volume of 750,000 gallons. It also includes a let-down system downstream of the existing vessel vent valves to control plant pressure in a range that permits the injection system to provide cooling water during a CLOHS accident.

As envisioned in scoping reviews, the project also includes upgrading the existing plant pressurizing pumps and associated systems to safety-related to provide cooling water for a CLOHS accident. The proposed modification will provide capability for system control from the ATR control room and/or from an alternative location. 


\begin{tabular}{|c|c|c|c|}
\hline $\begin{array}{c}\text { Evaluation } \\
\text { Criterion } \\
\text { No. }\end{array}$ & $\begin{array}{l}\text { Evaluation } \\
\text { Criteria }\end{array}$ & DOE-STD-1189 Discussion & $\begin{array}{c}\text { Emergency Firewater Injection System Replacement } \\
\text { Discussion }\end{array}$ \\
\hline 1 & $\begin{array}{l}\text { Add a new } \\
\text { building or } \\
\text { facility with a } \\
\text { material } \\
\text { inventory } \geq \\
\text { Hazard } \\
\text { Category } 3 \\
\text { (HC 3) limits } \\
\text { or increase } \\
\text { the HC of an } \\
\text { existing } \\
\text { facility? }\end{array}$ & $\begin{array}{l}\text { A new building may be a } \\
\text { structure within an existing } \\
\text { facility segment. That structure } \\
\text { may or may not have direct } \\
\text { process ties to the remainder of } \\
\text { the segment/process. The } \\
\text { requirements of } \\
\text { DOE-STD-1027-92, Change } \\
\text { Notice 1, September 1997, are } \\
\text { used in evaluating Hazard } \\
\text { Categorization impacts. }\end{array}$ & $\begin{array}{l}\text { No, it does not change the } \mathrm{HC} \text { of the existing facilities and, by itself, any } \\
\text { replacement structure, such as an injection pump building, will be a } \\
\text { non-radiological facility. } \\
\text { As envisioned, the proposed modification adds a replacement structure to } \\
\text { house the replacement EFIS pumps and valves. The building is likely to } \\
\text { be physically separate from the ATR reactor building and will not hold any } \\
\text { radiological inventory (i.e., will be a non-radiological building); however, it } \\
\text { will be one of the buildings/structures that make up the ATR Complex } \\
\text { Advanced Test Reactor as currently listed in the UFSAR. As stated in the } \\
\text { UFSAR (Section ES-2), these buildings and structures are necessary for } \\
\text { safe operation of ATR. }\end{array}$ \\
\hline 2 & $\begin{array}{l}\text { Change the } \\
\text { footprint of an } \\
\text { existing HC 1, } \\
2 \text { or } 3 \text { facility } \\
\text { with the } \\
\text { potential to } \\
\text { adversely } \\
\text { affect any } \\
\text { safety class } \\
\text { (SC) or safety } \\
\text { significant } \\
\text { (SS) safety } \\
\text { function or } \\
\text { associated } \\
\text { structure, } \\
\text { system and } \\
\text { component } \\
\text { (SSC)? }\end{array}$ & $\begin{array}{l}\text { A change in the footprint of an } \\
\text { existing facility requires the } \\
\text { identification and evaluation of } \\
\text { any potential adverse impacts } \\
\text { on SC or SS safety functions or } \\
\text { associated SSC (e.g., structural } \\
\text { qualification, evacuation egress } \\
\text { path, fire suppression spray } \\
\text { pattern) or safety analysis } \\
\text { assumptions. Changes that may } \\
\text { involve adverse impacts require } \\
\text { careful attention to maintaining } \\
\text { adherence to applicable } \\
\text { engineering standards and } \\
\text { nuclear safety design criteria. }\end{array}$ & $\begin{array}{l}\text { Functionally, the footprint is unchanged. Equivalent new structures will } \\
\text { replace existing structures that house the current injection system pumps } \\
\text { and store water for emergency injection. For purposes of this major } \\
\text { modification determination, it is anticipated that the replacement EFIS, } \\
\text { potentially including a replacement pump house, recirculation system, and } \\
\text { demineralized water tank, will be classified as safety-related SSCs. The } \\
\text { design for the replacement safety-related SSCs requires careful attention to } \\
\text { maintaining adherence to applicable and credited engineering and nuclear } \\
\text { safety design criteria (e.g., active seismic qualification, redundancy and } \\
\text { diversity for safety functions) to ensure no adverse impacts to their } \\
\text { designated safety functions. } \\
\text { Safety classification will be determined by the INL based on the safety } \\
\text { analysis/probabilistic risk assessment concurrent with the design } \\
\text { maturation. }\end{array}$ \\
\hline
\end{tabular}




\begin{tabular}{|c|c|c|c|}
\hline $\begin{array}{c}\text { Evaluation } \\
\text { Criterion } \\
\text { No. }\end{array}$ & $\begin{array}{l}\text { Evaluation } \\
\text { Criteria }\end{array}$ & DOE-STD-1189 Discussion & $\begin{array}{c}\text { Emergency Firewater Injection System Replacement } \\
\text { Discussion }\end{array}$ \\
\hline 3 & $\begin{array}{l}\text { Change an } \\
\text { existing } \\
\text { process or } \\
\text { add a new } \\
\text { process } \\
\text { resulting in the } \\
\text { need for a } \\
\text { safety basis } \\
\text { change } \\
\text { requiring DOE } \\
\text { approval? }\end{array}$ & $\begin{array}{l}\text { A change to an existing process } \\
\text { may negatively affect the } \\
\text { efficacy of an approved set of } \\
\text { hazard controls for a given event } \\
\text { or accident. Likewise, potential } \\
\text { safety concerns associated with } \\
\text { a new process may not be } \\
\text { adequately addressed by the } \\
\text { existing approved control sets. } \\
\text { In this case, it is assumed that } \\
\text { the existing analyses addressed } \\
\text { the hazards associated with the } \\
\text { new or revised process, but the } \\
\text { specified control set(s) may no } \\
\text { longer be valid. The evaluation } \\
\text { of any new hazards introduced } \\
\text { by the revised or new process } \\
\text { should be addressed via } \\
\text { Criterion } 6\end{array}$ & $\begin{array}{l}\text { Yes. The proposed activity does change an existing process resulting in a } \\
\text { safety basis change that requires DOE approval. } \\
\text { The current safety-related EFIS uses firewater, supplied by redundant safety- } \\
\text { related diesel engine driven firewater pumps, valves, and piping for } \\
\text { emergency core cooling mitigation for a LOCA. The current design has no } \\
\text { provisions for collection and reuse of the water (i.e. primary coolant) that } \\
\text { leaks from the LOCA breach point into the reactor building. The replacement } \\
\text { EFIS that is currently envisioned to replace the current EFIS as the primary } \\
\text { emergency coolant injection system, incorporates two fundamental process } \\
\text { changes: 1) It injects demineralized water rather than firewater. } \\
\text { Demineralized water will be produced and stored in a } 750,000 \text { gallon tank. } \\
2 \text { ) The replacement EFIS includes a recirculation system that will recover } \\
\text { primary coolant that leaks from the LOCA breach into the reactor building. } \\
\text { New recirculation pumps will draw suction from reactor subbasement low } \\
\text { point that act as collection points for the leakage and recirculate the primary } \\
\text { coolant for cooling the reactor core. } \\
\text { The efficacy of the replacement EFIS is dependent on many system design } \\
\text { factors that require careful attention to maintaining adherence to applicable } \\
\text { and credited engineering and nuclear safety design criteria (e.g., active } \\
\text { seismic qualification, redundancy, and diversity for safety functions) to ensure } \\
\text { no adverse impacts to their designated safety functions. The following are a } \\
\text { few of the factors to be considered: } 1 \text { ) The recirculation sumps must provide } \\
\text { protection against debris blocking flow to the sumps, damaging or jamming } \\
\text { the pumps, or plugging or blocking other flow restriction points in the flow path } \\
\text { through the core. } 2 \text { ) Seismic/NPH qualification of replacement SSCs to } \\
\text { include the storage tank and facility housing the replacement EFIS injection } \\
\text { pumps. 3) Diversity and redundancy for power to the pumps and other active } \\
\text { components/controls for the injection system(s). }\end{array}$ \\
\hline
\end{tabular}




\begin{tabular}{|c|c|c|c|}
\hline $\begin{array}{c}\text { Evaluation } \\
\text { Criterion } \\
\text { No. }\end{array}$ & $\begin{array}{l}\text { Evaluation } \\
\text { Criteria }\end{array}$ & DOE-STD-1189 Discussion & $\begin{array}{c}\text { Emergency Firewater Injection System Replacement } \\
\text { Discussion }\end{array}$ \\
\hline 4 & $\begin{array}{l}\text { Utilize new } \\
\text { technology or } \\
\text { government } \\
\text { furnished } \\
\text { equipment } \\
\text { (GFE) not } \\
\text { currently in } \\
\text { use or not } \\
\text { previously } \\
\text { formally } \\
\text { reviewed / } \\
\text { approved by } \\
\text { DOE for the } \\
\text { affected } \\
\text { facility? }\end{array}$ & $\begin{array}{l}\text { This assessment should include } \\
\text { consideration of the impact that } \\
\text { the use of new technology } \\
\text { (including technology scale-up } \\
\text { issues) or GFE may have on the } \\
\text { ability to specify the applicable } \\
\text { nuclear safety design criteria } \\
\text { with a high degree of certainty in } \\
\text { the early stages of the project. } \\
\text { Additionally, refer to GFE } \\
\text { discussion in Section } 8.3 \text {. GFE } \\
\text { may have a technical baseline } \\
\text { that is not directly and fully } \\
\text { supportive of the project } \\
\text { functional and performance } \\
\text { requirements. An example } \\
\text { would be employing a new } \\
\text { technology for removal of certain } \\
\text { nuclides from a waste stream. }\end{array}$ & $\begin{array}{l}\text { No. It is not anticipated that new technology will be utilized in this project. } \\
\text { It is unlikely that the specific makes and models for the replacement EFIS } \\
\text { injection and recirculation pumps will be identical to that previously } \\
\text { approved by DOE for ATR. However, it is anticipated that the proposed } \\
\text { equipment will be functionally equivalent to equipment that is current } \\
\text { technology to the nuclear power industry. }\end{array}$ \\
\hline
\end{tabular}




\begin{tabular}{|c|c|c|c|}
\hline $\begin{array}{c}\text { Evaluation } \\
\text { Criterion } \\
\text { No. }\end{array}$ & $\begin{array}{l}\text { Evaluation } \\
\text { Criteria }\end{array}$ & DOE-STD-1189 Discussion & $\begin{array}{c}\text { Emergency Firewater Injection System Replacement } \\
\text { Discussion }\end{array}$ \\
\hline 5 & $\begin{array}{l}\text { Create the } \\
\text { need for new } \\
\text { or revised } \\
\text { safety SSCs? }\end{array}$ & $\begin{array}{l}\text { Consideration should be given } \\
\text { to the relative complexity of the } \\
\text { controls and the ease with which } \\
\text { the controls can be } \\
\text { implemented. The use of a } \\
\text { complicated multi-channel } \\
\text { Safety Class seismically } \\
\text { qualified instrumented system to } \\
\text { provide multiple interlock and } \\
\text { alarm functions would typically } \\
\text { pose a higher risk to the project } \\
\text { than the use of a safety } \\
\text { significant passive design } \\
\text { feature. The degree of design } \\
\text { and regulatory uncertainty } \\
\text { should be addressed for this } \\
\text { criterion for the development, } \\
\text { review, and approval of new or } \\
\text { revised safety analysis and } \\
\text { attendant controls (e.g., } \\
\text { presence of multiple } \\
\text { regulatory/technical agencies on } \\
\text { a single project). }\end{array}$ & $\begin{array}{l}\text { Yes. Substantial operational differences in the replacement EFIS will need } \\
\text { to be addressed in the safety analysis. This potentially includes the use of } \\
\text { electric driven injection pumps to replace the existing safety-related diesel } \\
\text { engine driven pumps, the use of demineralized water to replace untreated } \\
\text { fire water, and the addition of recirculation pumps to recover coolant } \\
\text { leakage from a LOCA. The classification of the existing EFIS, if retained } \\
\text { as a defense-in-depth system, will also need to be determined based on } \\
\text { the results of supporting safety analysis/probabilistic risk assessment. }\end{array}$ \\
\hline
\end{tabular}




\begin{tabular}{|c|c|c|c|}
\hline $\begin{array}{l}\text { Evaluation } \\
\text { Criterion } \\
\text { No. }\end{array}$ & $\begin{array}{l}\text { Evaluation } \\
\text { Criteria }\end{array}$ & DOE-STD-1189 Discussion & $\begin{array}{c}\text { Emergency Firewater Injection System Replacement } \\
\text { Discussion }\end{array}$ \\
\hline 6 & $\begin{array}{l}\text { Involve a } \\
\text { hazard not } \\
\text { previously } \\
\text { evaluated in } \\
\text { the } \\
\text { Documented } \\
\text { Safety } \\
\text { Analysis? }\end{array}$ & $\begin{array}{l}\text { Hazards can include the } \\
\text { introduction of an accident or } \\
\text { failure mode of a different type } \\
\text { from that previously analyzed in } \\
\text { addition to radiological or } \\
\text { toxicological hazards. The need } \\
\text { to address a new hazard early in } \\
\text { the design process may lead to } \\
\text { some degree of uncertainty } \\
\text { related to the proper } \\
\text { specification of applicable } \\
\text { nuclear safety design criteria. In } \\
\text { such cases, this uncertainty } \\
\text { should be addressed within this } \\
\text { evaluation. }\end{array}$ & $\begin{array}{l}\text { No. As discussed in Section } 3 \text { of this document, replacement of the EFIS } \\
\text { does not involve any new hazards not previously evaluated in the ATR } \\
\text { UFSAR. }\end{array}$ \\
\hline \multicolumn{4}{|c|}{$\begin{array}{l}\text { Summary and Recommendation: Three of the six criteria (Criterion } 2,3 \text {, and } 5 \text { ) were tripped in this major modification evaluation. As discussed } \\
\text { above, the proposed project does not introduce any new significant hazards. However, the proposed strategy for replacing the EFIS injection of } \\
\text { firewater with a system that uses demineralized water and a recirculating system that recovers and reuses primary coolant leakage from a } \\
\text { LOCA breach will require significant safety basis changes requiring DOE approval (see Criterion No. } 3 \text { and } 5 \text { discussions above). The strategy } \\
\text { requires careful attention to maintaining adherence to applicable and credited engineering and nuclear safety design criteria (e.g., active seismic } \\
\text { qualification, redundancy, and diversity for safety functions) to ensure no adverse impacts to their designated safety functions. Based on these } \\
\text { considerations, it is concluded that this project constitutes a major modification and will, therefore, require the development, review, and } \\
\text { approval of a PDSA. Therefore, it is recommended that the project proceed accordingly. Also since DOE-STD-3009 is not the safe harbor } \\
\text { format for the ATR UFSAR, the SDS must establish the expectations and the format for the preliminary safety design report (PSDR) (if needed) } \\
\text { and PDSA to integrate the subject major modifications into the ATR UFSAR. }\end{array}$} \\
\hline
\end{tabular}


INL/EXT-11-22066

Revision 0

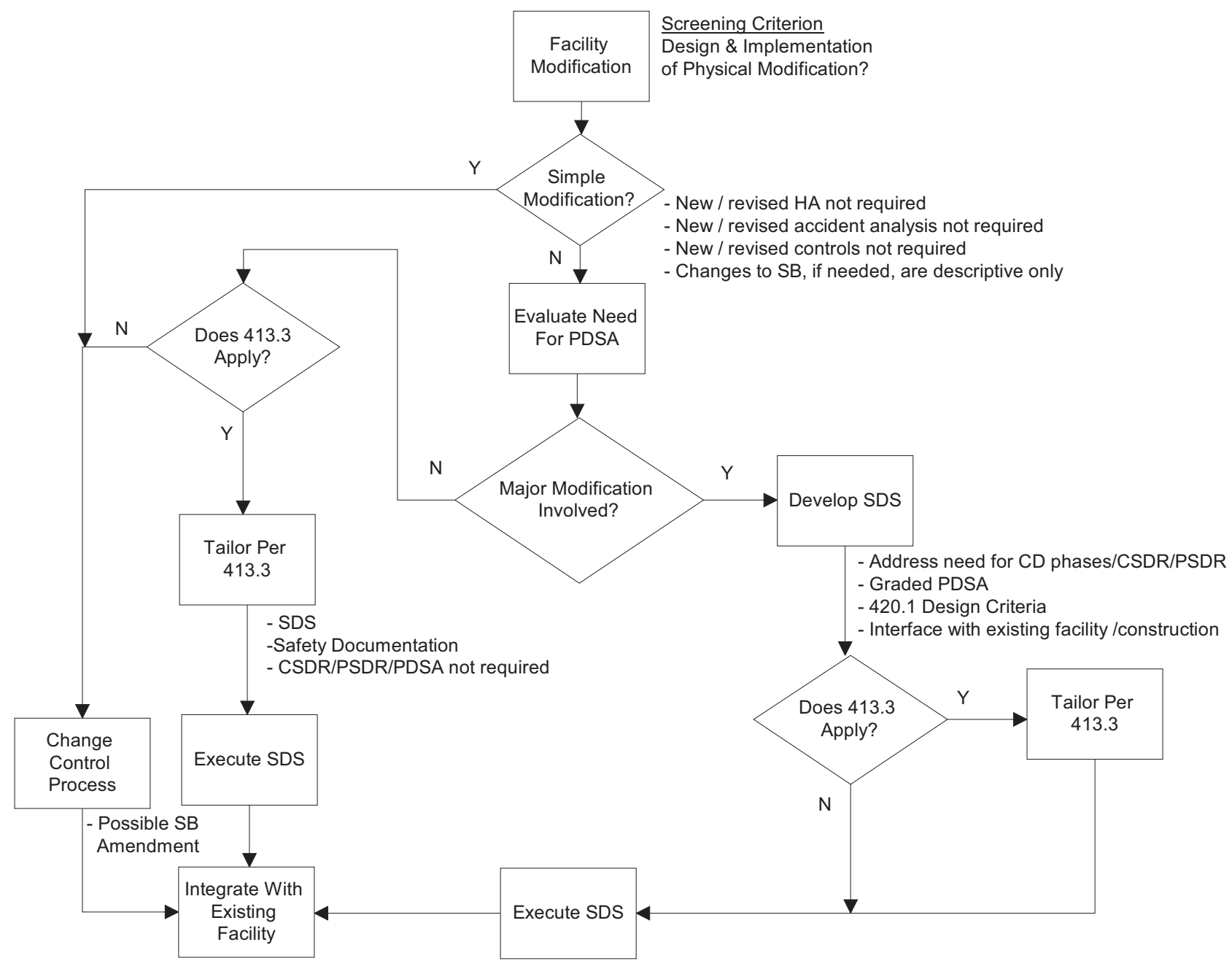

Figure 2. Facility modification process (taken from DOE-STD-1189, Fig 8-1). 


\section{CONCLUSION}

The major modification criteria evaluation of the project pre-conceptual design identified several issues that lead to the conclusion that the project is a major modification:

1. Evaluation Criteria \#2 (Footprint change). It is anticipated that the replacement EFIS, potentially including a replacement pump house, recirculation system, and demineralized water tank, will be classified as safety-related SSCs. The design for the replacement safetyrelated SSCs requires careful attention to maintaining adherence to applicable and credited engineering and nuclear safety design criteria (e.g., active seismic qualification, redundancy, and diversity for safety functions) to ensure no adverse impacts to their designated safety functions.

2. Evaluation Criteria \#3 (Change of existing process). The replacement EFIS that is currently envisioned to replace the EFIS as the primary emergency coolant injection system, incorporates two fundamental process changes: 1) It injects demineralized water rather than firewater. Demineralized water will be produced and stored in a replacement 750,000 gallon tank. 2) The replacement EFIS includes a recirculation system that will recover primary coolant that leaks from the LOCA breach into the reactor building. New recirculation pumps will draw suction from reactor subbasement low point that act as collection points for the leakage and recirculate the primary coolant for cooling the reactor core. These process changes will result in the need for revisions to the safety basis and require DOE approval.

3. Evaluation Criteria \#5 (Create the need for new or revised safety SSCs). It is expected that the proposed activity will result in a revised list of safety-related SSCs. Specifically, it is anticipated that the replacement EFIS injection pumps, recirculation pumps, associated valves and piping and control systems will be classified as safety-related. The classification of the existing EFIS, if retained as a defense-in-depth system, will also need to be determined based on the results of supporting safety analysis/probabilistic risk assessment.

As discussed in 1,2, and 3 above, the positive major modification determination is driven by the need to carefully establish the engineering and nuclear safety design criteria for new safety-related SSCs and structures. Since the proposed project does not introduce significant new hazards, the safety analysis will need to be tailored appropriately as discussed in the following text from DOE-STD-1189, Chapter 8:

"Where a major modification is found to exist, an SDS must be developed that addresses (1) the need for a CSDR or PSDR (as well as the required PDSA) to support project phases, (2) the graded content of the PDSA necessary to support the design and modification, (3) the application of nuclear safety design criteria, and (4) the interface with the existing facility, its operations, and construction activities."

\section{REFERENCES}

1. Mission Need Statement for Advanced Test Reactor Reliability Sustainment Project, March 2011 Draft.

2. MPR Associates Inc. Letter, Weston Pollock to Paul Henslee, Subject: ATR EFIS Replacement System; Supporting Information for Scoping Estimate, March 23, 2011.

3. SAR-153, "Upgraded Final Safety Analysis Report for the Advanced Test Reactor," Rev. 30, February 2011. 
4. DOE-STD-1189-2008, "Integration of Safety into the Design Process," Department of Energy, March 2008.

5. $\quad 10$ CFR 830, Subpart B, "Nuclear Safety Management," Code of Federal Regulations, Office of the Federal Register, current revision.

6. DOE-STD-3009-94, Change Notice 3, "Preparation Guide for U. S. Department of Energy

Nonreactor Nuclear Facility Documented Safety Analyses,” Department of Energy, March 2006. 